\title{
Are Performance Audits Useful? A Comparison of EU Practices
}

\section{Lourdes Torres', Ana Yetano', and Vicente Pina'}

\begin{abstract}
Performance audits allow audit institutions to contribute to the improvement of the economy, efficiency, and/or effectiveness of public sector entities through the recommendations of their reports. To assess the impact of the performance audits carried out by EUSupreme and Regional Audit Institutions, this article analyzes whether these recommendations are implemented in practice or not. The results show that there are two main ways in which the recommendations included in the performance audit reports produce an impact: the Anglo-American way, based on auditee actions and follow-up processes, and the Germanic way, based on parliamentary action.
\end{abstract}

\section{Keywords}

performance audits, public administration styles, logic, impact, Supreme Audit Institutions, Regional Audit Institutions

\section{Introduction}

The global economic downturn has driven most governments to implement cutbacks and austerity measures while demands for more and better public services are greater than ever (Pollitt, 2010). Pressures for restraining the growth of public expenditure and for increasing efficiency and effectiveness

\footnotetext{
IUniversity of Zaragoza, Spain
}

\section{Corresponding Author:}

Ana Yetano, University of Zaragoza, Faculty of Economics and Business, C/Gran Vía n2, Zaragoza 50.005, Spain.

Email: ayetano@unizar.es 
have been intensified since the global economic crisis in 2008 (Pollitt \& Bouckaert, 2011) and, at the same time, mechanisms for improving the public sector, such as performance audits, have received increasing academic and professional attention.

The number of Supreme and Regional Audit Institutions (SAI and RAI) around the world that have a legal obligation to carry out performance audits have increased and many other SAIs and RAIs have expressed their interest in them (Arthur, Rydland, \& Amundsen, 2012). Professionals and academics consider performance auditing to be a key mechanism in the improvement of the public sector in this period of austerity ${ }^{1}$.

An increasing body of research analyzes the impact and usefulness ${ }^{2}$ of performance audit reports on public sector efficiency and effectiveness (Morin, 2001, 2004, 2008; Reichborn-Kjennerud, 2013, 2014, 2015; Van Loocke \& Put, 2011). We aim to contribute to the analysis of the effectiveness of performance audit reports through a comparative study of EU RAIs and SAIs concerning the implementation of the recommendations of these reports.

Comparative research in public management reforms identifies the international trends and broad models that are present in Europe. In addition, it helps to determine whether differences between countries with different public administration styles, such as France and the United Kingdom, are still the same as they were 30 years ago (Pollitt \& Bouckaert, 2011). In this article, international comparative research will help us to identify whether there are different approaches to performance audits in Europe and to analyze the impact of these approaches. This study compares the practices of the performance audits carried out by the EU SAIs and RAIs and analyzes whether the recommendations of their reports produce an impact and whether this impact comes from auditee action, governmental action, and/or parliamentary debate. This parliamentary debate is key for the conceptual and interactive impact of performance audits (Reichborn-Kjennerud, 2014)

Although most performance audit studies have focused on SAIs (among others, Arthur et al., 2012; Morin, 2008; Pollitt, 2003; Pollitt \& Bouckaert, 2011; Pollitt et al., 1999; Reichborn-Kjennerud, 2015; Torres \& Pina, 1999; Yetano, 2005), in countries with a regional configuration, RAIs also carry out performance audits. In fact, in countries such as Germany and Spain, most performance audits are carried out by RAIs rather than by SAIs (Yetano, 2014). Thus, the results of RAIs activity need to be studied to give an overall view of performance audit in Europe.

The objective of this article is the identification of patterns in the implementation of performance audits and their impact. The analysis of the performance audit activity and its impact in Europe aims to answer the following 
questions: What is the current development of performance audits in the EU? When do performance audits generate impacts? Who implements the recommendations after a performance audit? The answers to these questions will help us to understand whether performance auditing has an impact on governmental management or whether it is merely a rhetorical instrument.

The rest of the article is organized as follows: Section "Variations in the Impact of Performance Audits" explains the main contextual points of reference of this study. "Methodology and Data" section describes the methodological aspects, and the section "Analysis of Results" contains the analysis of results. And the final two sections address the discussion and conclusions.

\section{Variations in the Impact of Performance Audits}

Although performance audits are intended to contribute to improving the operations of the audited entities (Reichborn-Kjennerud, 2015), their effectiveness as an instrument to control and to improve public administration should not be taken for granted (Morin, 2001). Performance audits should produce actions. We will look at impact as the capacity to produce these actions, ${ }^{3}$ either by changes in the practices of the auditee (usually measured by the implementation of recommendations) or by influencing the political debate (usually measured by the amount of attention gained in Parliament; Lonsdale, 2000). As a result of increasing interest in the impact of performance auditing, academics have looked at it from different perspectives (Van Loocke \& Put, 2011). Some authors focus on its effects at the macro-level, analyzing its impact in terms of fiscal policy, government effectiveness, and capital productivity (Blume \& Voigt, 2007; Schelker, 2008). At the microlevel, a common measure of this impact has been the recommendations implemented (Alon, 2007; Brown \& Craft, 1980; Hatherly \& Parker, 1988; Johnston, 1988; Milgrom \& Schwartz, 2008). Pollitt et al. (1999) find that the proportion of recommendations of performance audit reports implemented is the most common measure of effect used by the UK National Audit Office, the Swedish Riksrevisionsverket (RRV), and the Dutch Algemene Rekenkamer (AR). Similarly, Van Loocke and Put (2011) indicate that the European Court of Auditors found that the most commonly used indicator of the impact of performance audits is the recommendations implemented or accepted. Morin (2001, 2004, 2008) and Reichborn-Kjennerud (2013, 2014, 2015) measure the impact of performance audits based on the opinions of the auditees and on their contribution to the public debate.

Performance audits, like many public sector reforms, are often criticized for not leading to action (Bouckaert \& Peters, 2002; Streib \& Poister, 1999; Torres, Pina, \& Yetano, 2011). The challenge that audit institutions must 
overcome is the lack of implementation of their recommendations (van Zyl, Ramkumar, \& de Rencio, 2009).

To interpret the adoption (real and rhetorical) and adaptation of public sector initiatives, institutional theory has been extensively used by academics in recent years (Johnsen, 2005; Pina, Torres, \& Yetano, 2009; Ribeiro \& Scapens, 2006). This theory is mostly concerned with the diffusion and spread of organizational models within a given organizational environment and with understanding organizations within larger social and cultural systems (DiMaggio \& Powell, 1983; Oliver, 1991). It assumes that a common way of gaining legitimacy is an alignment with rationalized institutional myths (Meyer \& Rowan, 1977). Isomorphism, a concept embedded in institutional theory, can be used to predict that audit institutions would adopt performance audit as a "symbol" of efficiency and modernity. This prediction seems to be confirmed by the international diffusion of performance auditing. This adoption of internationally recognized "good practices" often creates a gap between rhetoric and reality (Pina et al., 2009). This gap or decoupling from the expected objectives is underpinned by the historical and sociological approaches of new institutionalism which suggests that the functioning and performance of institutions are historically and culturally embedded. Thus, it can be expected that performance audit may be a rhetorical instrument, in some cases, rather than a vehicle for change.

The variety of practices of performance audits (Shand \& Arnberg, 1996; Tillema \& ter Bogt, 2010) suggests that there is not only a dichotomy of rhetorical versus instrumental implementation (Burns \& Scapens, 2000; Siti-Nabiha \& Scapens, 2005) but also different ways of introducing performance audits that lead to action. The concept of logic ${ }^{4}$ could explain variations in the impact of performance audits. Lounsbury (2008) argued that the study of variations in practice should be focused on the primacy of culture, rather than relying on mimesis (Lounsbury, 2008; Lounsbury \& Ventresca, 2002). The socio-cultural contexts of organizations facilitate cognitive, normative, and regulative pressures that fundamentally shape organizational behavior (Scott, 2008). As a result, pressures of the institutional environment for the introduction of performance mechanisms may result in different configurations of the "same" reform. This approach implies substituting the idea of "diffusion as imitation," which involves the spread of a certain model to a number of passive recipients (Campbell, 2004), by the organizational adoption of reforms carried out by intelligent, performance-oriented managers who are conditioned by the cultural context.

Institutional environments are influenced by multiple and competing logics (Friedland \& Alford, 1991; Lounsbury, 2007), which, as shown by Lounsbury (2007), explain the various configurations of performance audit, "the variations on a theme” (Hood, 1995). The New Public Management (NPM) 
promoted a performance logic, or managerial logic (Reichborn-Kjennerud, 2014), that became embedded with other logics, rooted in geographical and cultural differences and broader belief systems. The logic based on culture explains variations in practice and provides legitimacy to specific actions and solutions (Friedland \& Alford, 1991; Lounsbury, 2007). Pollitt et al. (1999) argued that performance audit was more fruitfully adopted by countries with a common law tradition than by those with a strong administrative tradition. Different logics, like different public administration styles, lead to different approaches to performance audits that affect their impact and effectiveness. The national context of public administrations is frequently used to explain variations in public sector reforms (Dunleavy \& Hood, 1994; Kickert, 1997, 2005; Pina et al., 2009; Pollitt \& Bouckaert, 2011). The public administration style is an institutional logic, represented by the organizational and administrative culture, historical background, and legal structural elements (Pina et al., 2009), which is usually shared by a group of countries. A managerial logic is associated with Anglo-American countries while a state law logic is associated with Continental European countries (Reichborn-Kjennerud, 2014). The Anglo-American countries seem closer to performance-driven ideas, such as performance audits, while Continental European countries have been structurally and culturally less hospitable to this kind of reforms (Pina et al., 2009; Pollitt \& Bouckaert, 2011). However, Continental European countries have also responded to environmental pressures for improving public services by developing their own mix of reforms (Pollitt \& Bouckaert, 2011).

Anglo-American countries were more active in introducing performance budgeting, full accrual accounting, and performance measures. Audits were divided into financial-compliance audits and performance audits (Pollitt \& Bouckaert, 2011). Nordic countries have followed a similar model of public sector reforms; Sweden was considered a leader in the diffusion and implementation of effectiveness audits (Pollitt et al., 1999). Continental European countries aimed to modernize their traditional bureaucracy by making it more professional, efficient, and citizen friendly, but they considered traditional bureaucracy had virtues that should be preserved (probity, predictability, continuity, close attention to the law). Administrative practice, in Continental Europe, is still marked by an overriding legalistic philosophy where civil servants require specific legal training (Jann, 2003; Ongaro, 2008). The differences in public administration logic are expected to affect the diffusion of Performance Audits (PA).

Finally, differences in EU territorial structures require the study of the activity of the RAIs. RAIs in Austria, France, Germany, and Spain, in their respective territories, have external control of the economic and financial 
management of regional and local public sector entities and, in the United Kingdom, of local governments and the National Health Service (NHS) entities. Although close cooperation between the SAIs and the RAIs is common in each country, their competences are over different public bodies.

\section{Data and Method}

A questionnaire on performance audit was sent to the SAIs and RAIs of EU countries with the backing of the EURORAI. At national and supranational level, 29 questionnaires were sent to 27 SAIs plus Norway ${ }^{5}$ and the European Court of Auditors (ECA). At regional level, 83 questionnaires were sent to the RAIs of Austria, France, Germany, Poland, Spain, and the United Kingdom, countries that have a regional configuration of the auditing system. ${ }^{6}$ The questionnaire was focused on the effects of performance audits in terms of the implementation of the recommendations by the auditees and the actions carried out by parliaments or governments after the publication of the reports. Other questions included in the questionnaire were related to the externalization of services/activities as a consequence of the reports, the attention devoted by parliaments to the reports, the characteristics of the development of performance audits (resources devoted, number and type of reports, accountability of the results to citizens, contracting out), and the follow-up processes.

The data for this study were collected during 2012 and three reminders were sent to encourage SAIs and RAIs to fill in the questionnaire. The final sample consisted of 12 SAIs plus the ECA and 42 RAIs. ${ }^{7}$ The response rate at central and supranational level was $44 \%$ (13 out of the 29) and at regional level 50.6\% (42 out of the 83 RAIs).The SAIs were from Belgium, Cyprus, the Czech Republic, Denmark, Germany, Hungary, Latvia, Lithuania, Malta, Norway, Portugal, and Sweden, as well as the ECA. The RAIs included Austria (six of the nine RAIs of the country, 6/9), France (10/26), Germany (9/16), Spain (8/12), Poland (6/16), and the United Kingdom (3/4) (see Appendix A). The total sample included 17 countries (Austria, Belgium, Cyprus, Czech Republic, Denmark, France, Germany, Hungary, Latvia, Lithuania, Malta, Norway, Poland, Portugal, Spain, Sweden, and the United Kingdom) plus the ECA. The sample represented $73.8 \%$ of the population of the EU 27 plus Norway at the 1st of January 2012. As can be seen in Table 1, in the majority of cases, the respondent was the President, Auditor General, or Director. Around 22\% of the responses came from the Head of the International Department or Performance Department and $13 \%$ of the responses were from auditors. ${ }^{8}$ To verify and triangulate the data obtained through the questionnaire, we analyzed the performance reports or the summaries published on the web of these audit institutions during 2013. The 
Table I. Respondents to the Questionnaire.

\begin{tabular}{lccc}
\hline & $\begin{array}{c}\text { President, } \\
\text { director, or } \\
\text { auditor general }\end{array}$ & Auditor & $\begin{array}{c}\text { Head of the International } \\
\text { Department or } \\
\text { Performance Department }\end{array}$ \\
\hline SAls and ECA & 1 & 4 & 8 \\
RAls & $7.7 \%$ & $30.8 \%$ & $61.5 \%$ \\
Total sample & 35 & 3 & 4 \\
& $83.33 \%$ & $7.14 \%$ & $9.52 \%$ \\
& 36 & 7 & 12 \\
\hline
\end{tabular}

Note. SAI = Supreme Audit Institutions; ECA = European Court of Auditors; RAI = Regional Audit Institutions.

contents of the reports, that is to say, the objectives, recommendations, references to the follow-up processes, and their timeliness, were checked. ${ }^{9}$

Exploratory analysis of the data was carried out to identify the characteristics of the performance auditing practices. Multidimensional scaling (MDS) and cluster analysis (Ward method) were applied to identify homogeneous groups among the SAIs and RAIs studied to test to what extent logics/public administration styles condition performance audit characteristics. Previous international comparative studies (Pina et al., 2009) have shown that these techniques are complementary methods whose main function is to simplify the complex patterns of associations among different entities. The MDS and cluster analysis not only find homogeneous groups, but also help to provide a graphical representation of them. Cluster analysis classifies a collection of objects - in our study, RAIs/SAIs — into a small number of groups or clusters which are mutually exclusive. It allows the formation of groups within the MDS exhibit on a statistical basis.

After identifying the homogeneous groups, and considering the differences among them, three indexes were created by adding up the responses given to the questions (see Table 5). One is focused on the effects of performance audits and two are related to the logic/public administrative culture (Anglo-American vs. Continental European; see Table 5). The MannWhitney $U$ test detects whether there are statistical differences between the groups of cases with regard to the indexes developed later in this article.

\section{Analysis of Results}

First, the results of the MDS and cluster analysis, using the answers given to the questionnaire, are presented. These tools were used to detect the existence 


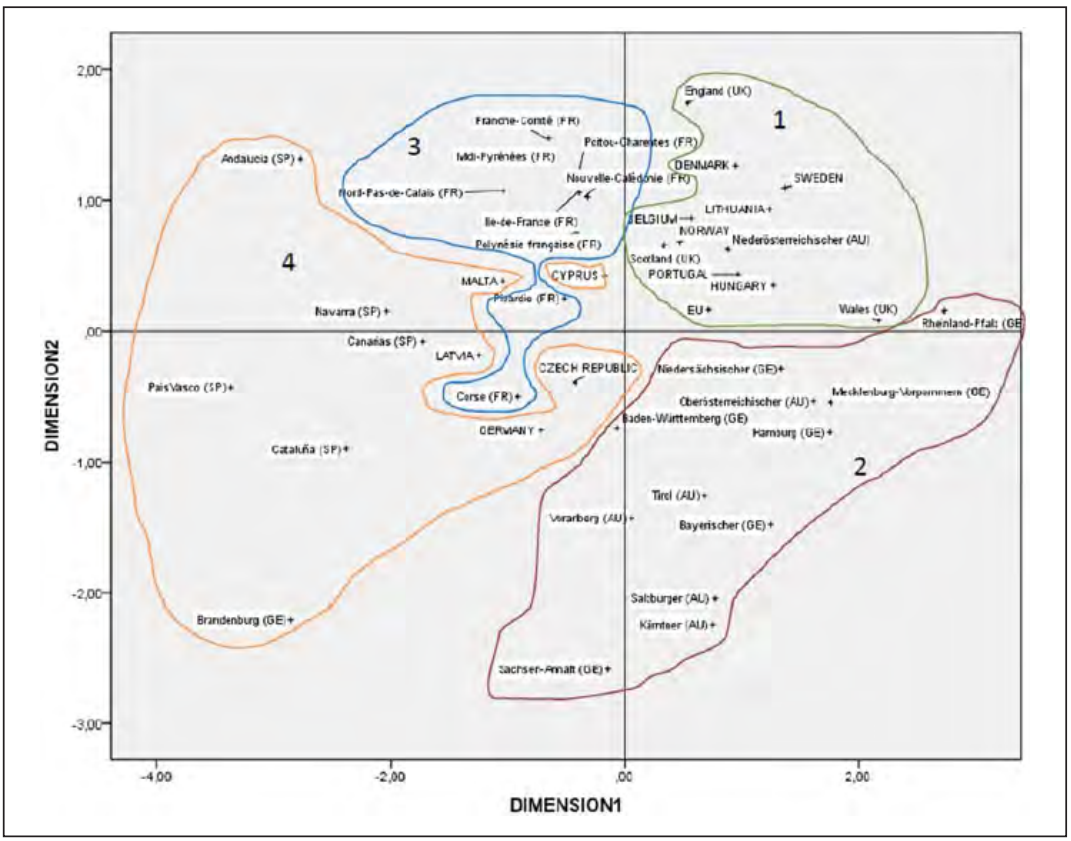

Figure I. MDS projection on Dimension I and Dimension 2.

Note. MDS = multidimensional scaling.

of groups of audit institutions with common behaviors. Second, a description and interpretation of each group is carried out. Finally, the results of three indexes built to test to what extent these differences are justified by different models of performance auditing are described.

Almost all the SAIs/RAIs that answered the questionnaire carry out performance audits, 44 of the 55 that answered, all those at national and supranational level, and many at regional level, Germany (8/9), Austria (6/6), Spain (5/8), France (9/10), Poland (0/6), the United Kingdom (3/3). Performance audits are compulsory in all the countries studied, except Poland: no Polish RAI carries out these audits. For our study, RAIs that do not carry out performance audit have been excluded.

Figure 1 shows the MDS results. On the basis of the MDS map, four groups have been identified using cluster analysis (see Appendix B): (a) the UK-Nordic group (12 cases), (b) the Germanic group (11 cases), (c) the French group (9 cases), and (d) "Other" (12 cases). The groups have been named considering the majority of the countries that integrate each group and 
the logics/public administration styles mentioned above. As in previous studies, not all the entities studied pertain to their foreseeable group (Pina et al., 2009). A comparison among groups and a descriptive analysis of them is carried out below, combining the information obtained from the questionnaire with the analysis of the websites.

Table 2 shows that $100 \%$ of audit institutions in the UK-Nordic group and $80 \%$ in the Germanic group issue more than 10 performance audits per year. This percentage is slightly lower in the French group, 67\%, and especially low in the "Other" group where only 50\% issue more than 10 reports and not all audit institutions issue performance audit reports every year. The higher number of reports issued, the amount of resources devoted to performance auditing and the existence, in most cases, of specific personnel show that, in the UK-Nordic, Germanic, and French groups, the audit institutions have developed a structure for performance audit (see Table 2). By contrast, the "Other" group seems to have a lower development of performance audits. The differences in contracting out or using the help of consultants (see Table 2) suggest that there are various configurations for performance auditing, which will be explored below.

\section{Group I-The UK-Nordic Group}

The first group includes the RAIs of the United Kingdom (England, Scotland, and Wales); the SAIs of Nordic countries (Denmark, Norway, and Sweden); Belgium, Hungary, Lithuania, and Portugal; the RAI of Niederösterreichischer of Austria; and the ECA. This group shows the highest number of performance audits (see Table 2). The number of performance audits exceeds 200 in Wales and 1,000 in England ${ }^{10}$ as they examine performance questions together with their yearly financial audits to local authorities. The audit institutions of this group devote significant resources in terms of budget to performance audits (between 25\% and 75\%). They prefer to carry out these audits internally and only contract experts for specific topics (see Table 2).

The audit institutions of the Nordic countries-Denmark, Norway, and Sweden - and the ECA focus more audits on effectiveness and on the three E's than the other audit institutions included in this group. An important characteristic of this group-except for Portugal and Hungary-is the timeliness of the reports. As can be seen in their webs, most of them publish the reports in the following year, as in the private sector.

In many audit institutions of this group, performance audits were developed at the same time that the audited entities introduced accounting and 


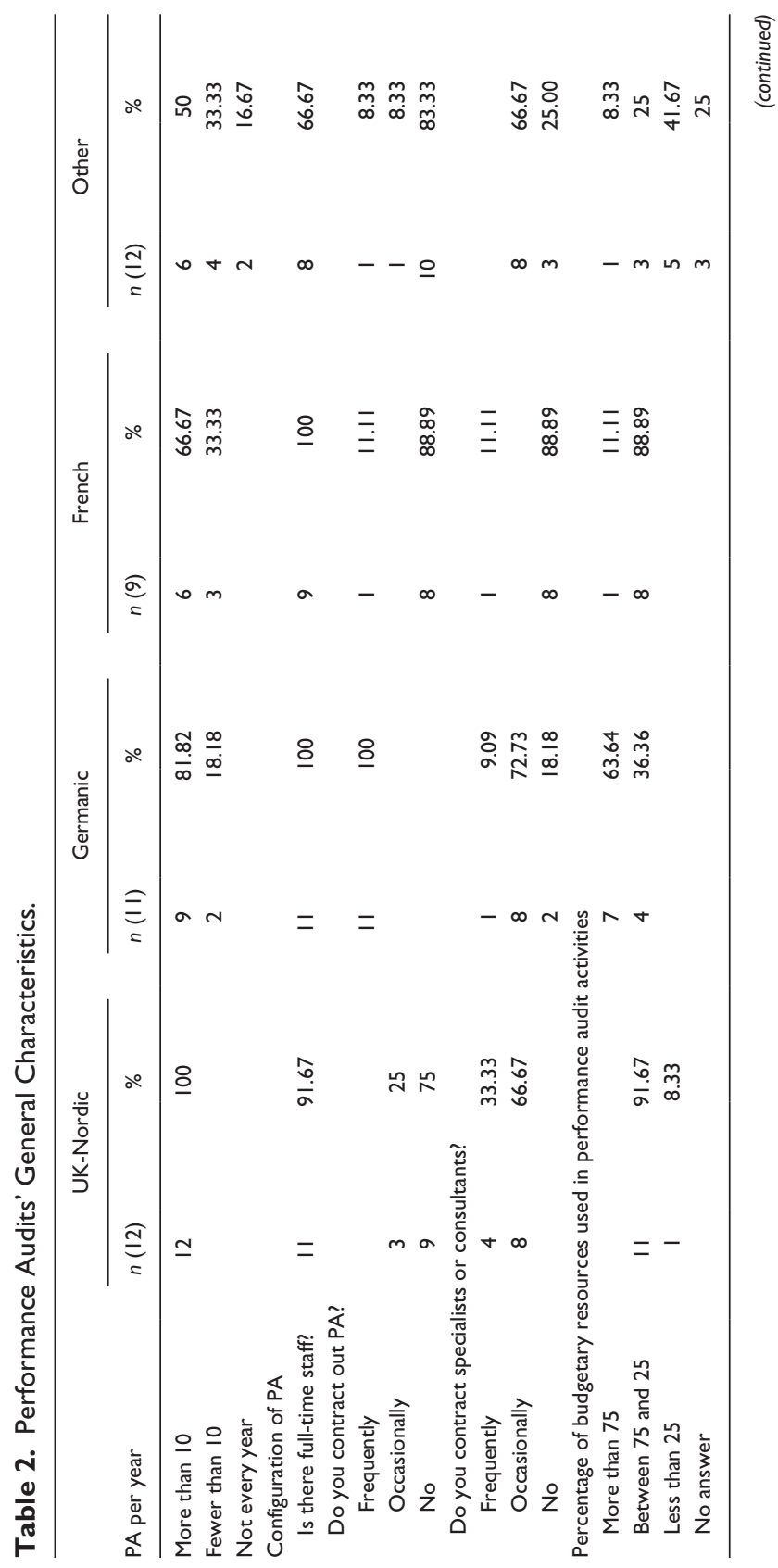




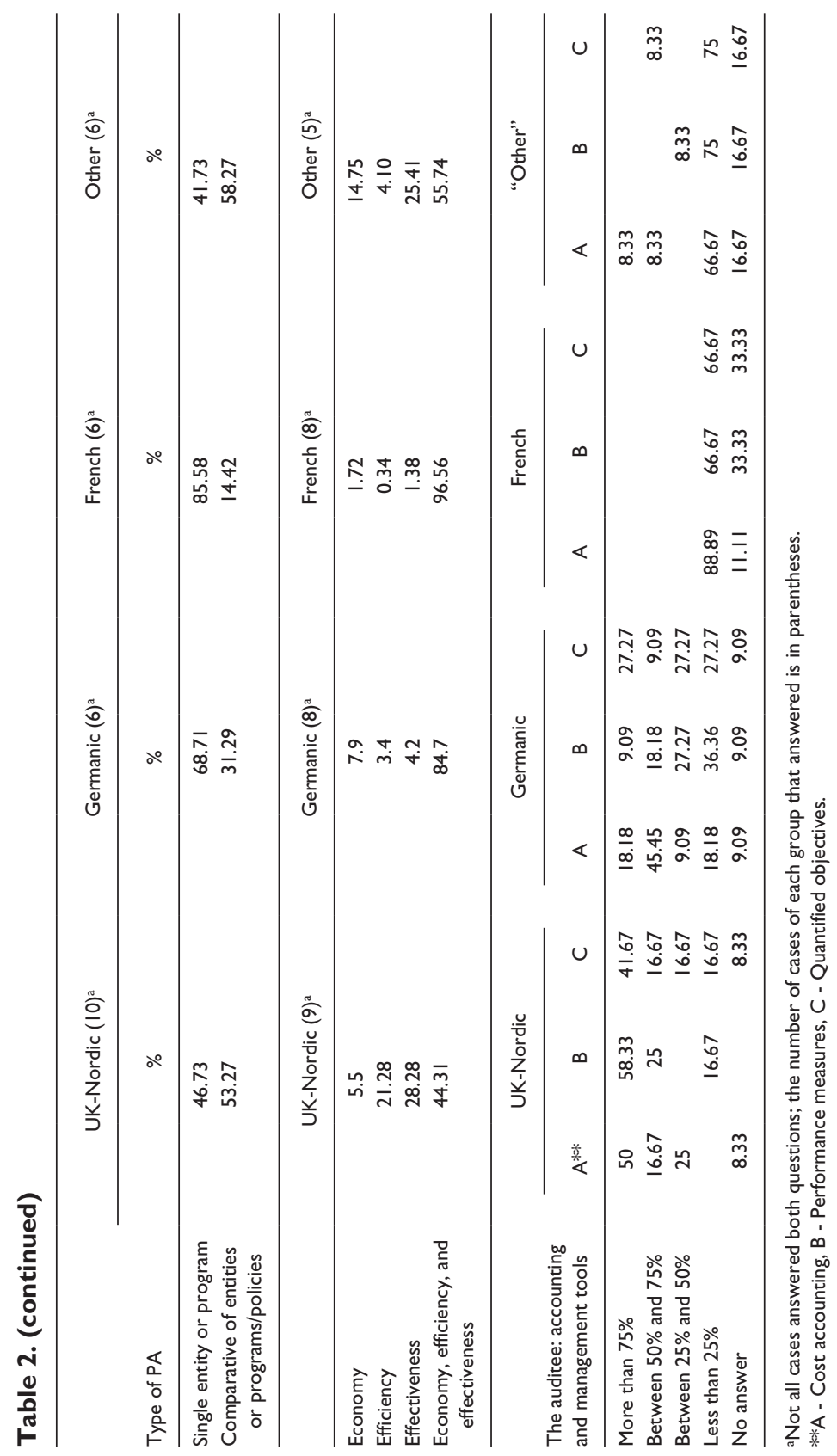


management tools which facilitated the implementation of performance audits. In all, $83 \%$ of the SAIs/RAIs say that more than $50 \%$ of the auditees have performance measures and $66 \%$ of the SAIs/RAIs say that more than $50 \%$ of the auditees have cost accounting and quantified objectives (see Table 3).

In this group, the entities audited usually implement the recommendations of the audit reports, and $92 \%$ of these RAIs/SAIs always go back to the entities to review whether their recommendations have been implemented through "follow-up processes" (see Table 3). For example, in its annual report, the Hungarian SAI includes statistics about the recommendations implemented by the auditees. In this group, more than 30\% of SAIs/ RAIs go back to analyze whether savings have been made (Table 4). These audit institutions present $75 \%$ of their performance audit reports in parliament for accountability purposes (Table 4). The changes after the performance audit reports are usually undertaken by the audited entity itself (see Table 4).

This group of audit institutions shows the highest level of transparency as full reports are always available on their websites, except for Wales (see Table 4). In most cases, they also publish a summary in their websites. In addition, some of them, such as the RAIs of the United Kingdom and the SAI of Lithuania, elaborate special summaries for the press.

\section{Group 2-The Germanic Group}

This group is made up of the RAIs of Germany and Austria: six from Germany (Bayerischer, Hamburg, Mecklenburg-Vorpommern, Niedersächsischer, Rheinland-Pfalz, and Sachen-Anhalt) and five from Austria (Kärntner, Oberösterreichischer, Salzburger, Tirol, and Vorarlberg). The only exceptions are the RAI of Niederösterreichischer (AU), included in Group 1, and the RAI of Brandenburg (GE), included in the "Other" group. The Germanic group also shows a high number of reports (Table 1). The RAIs of this group often contract out performance audits ( $90 \%$ do it frequently; see Table 2). The group devotes more budgetary resources (around 75\%) to performance auditing than the first group.

The analysis of the reports published in their webs shows that, in most cases, their focus is mainly on economy topics. A total of $63 \%$ of the audit institutions say that a high percentage of audited entities, more than $50 \%$, have implemented cost accounting. This enables their RAIs/SAIs to carry out economy audits. By contrast, only a low percentage of these entities have performance measures and quantified objectives (see Table 3). 


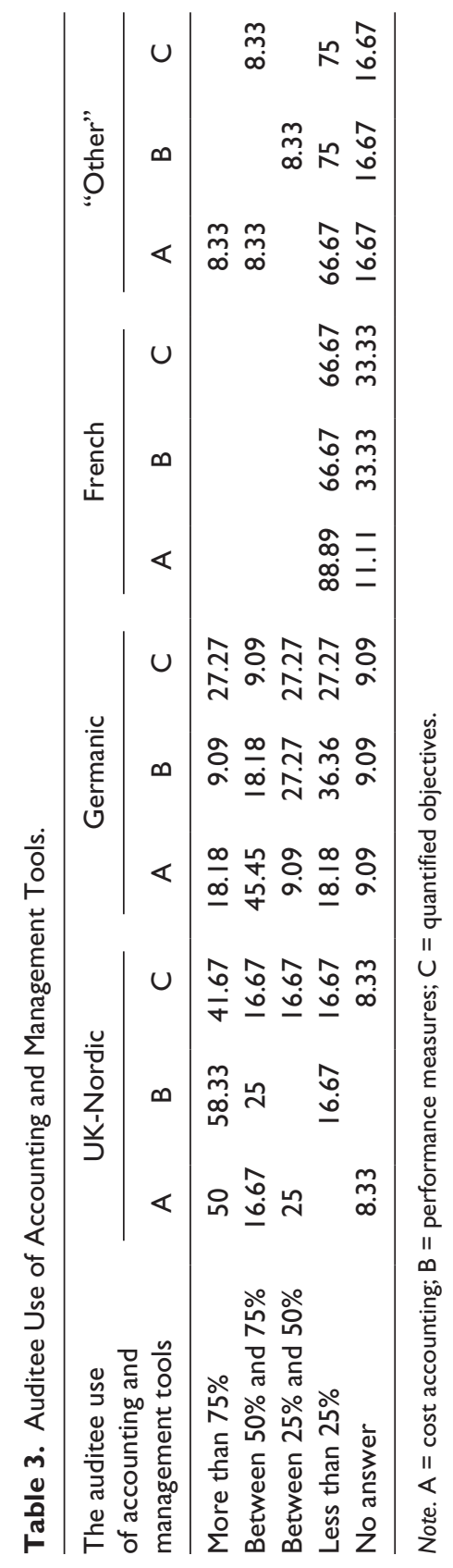




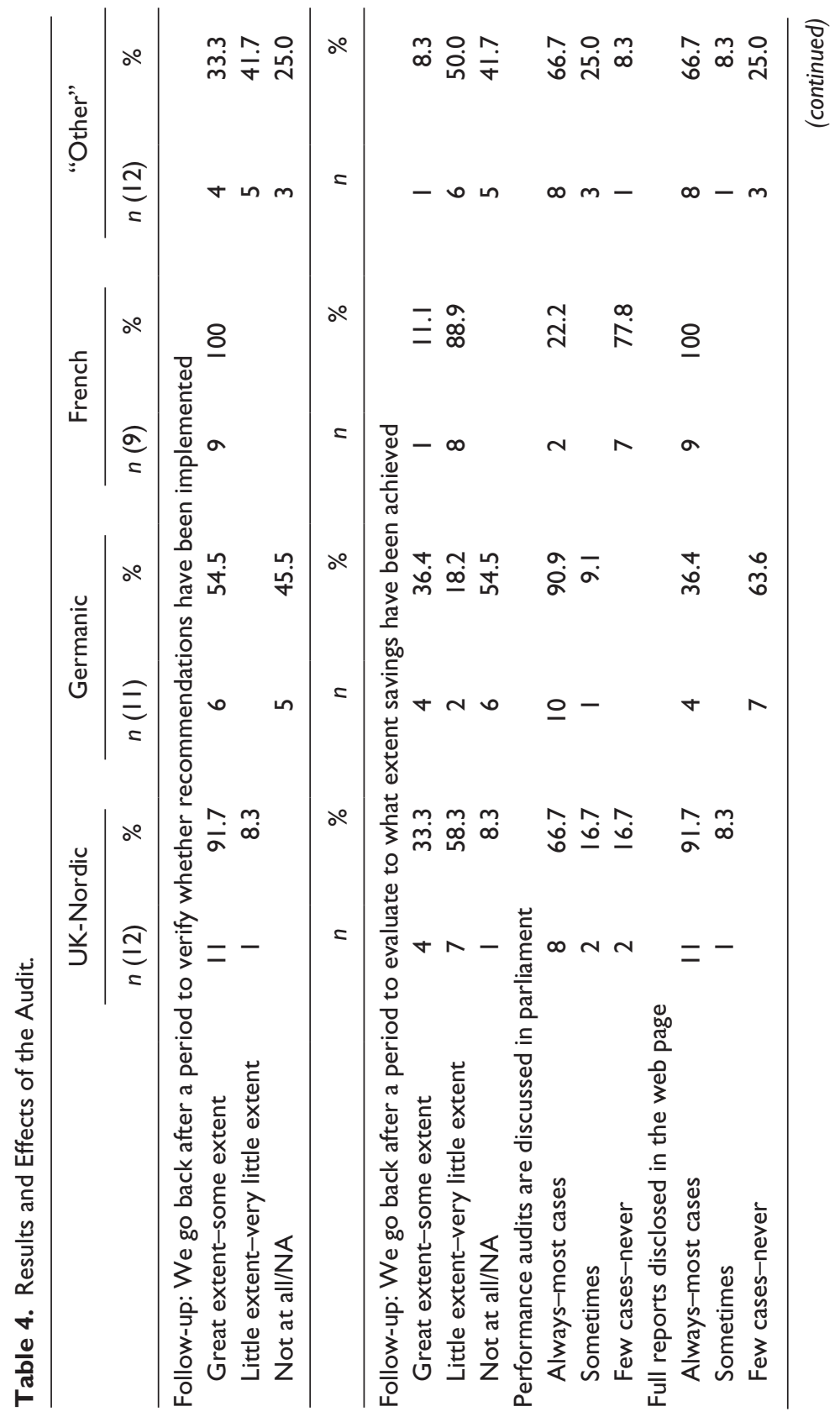




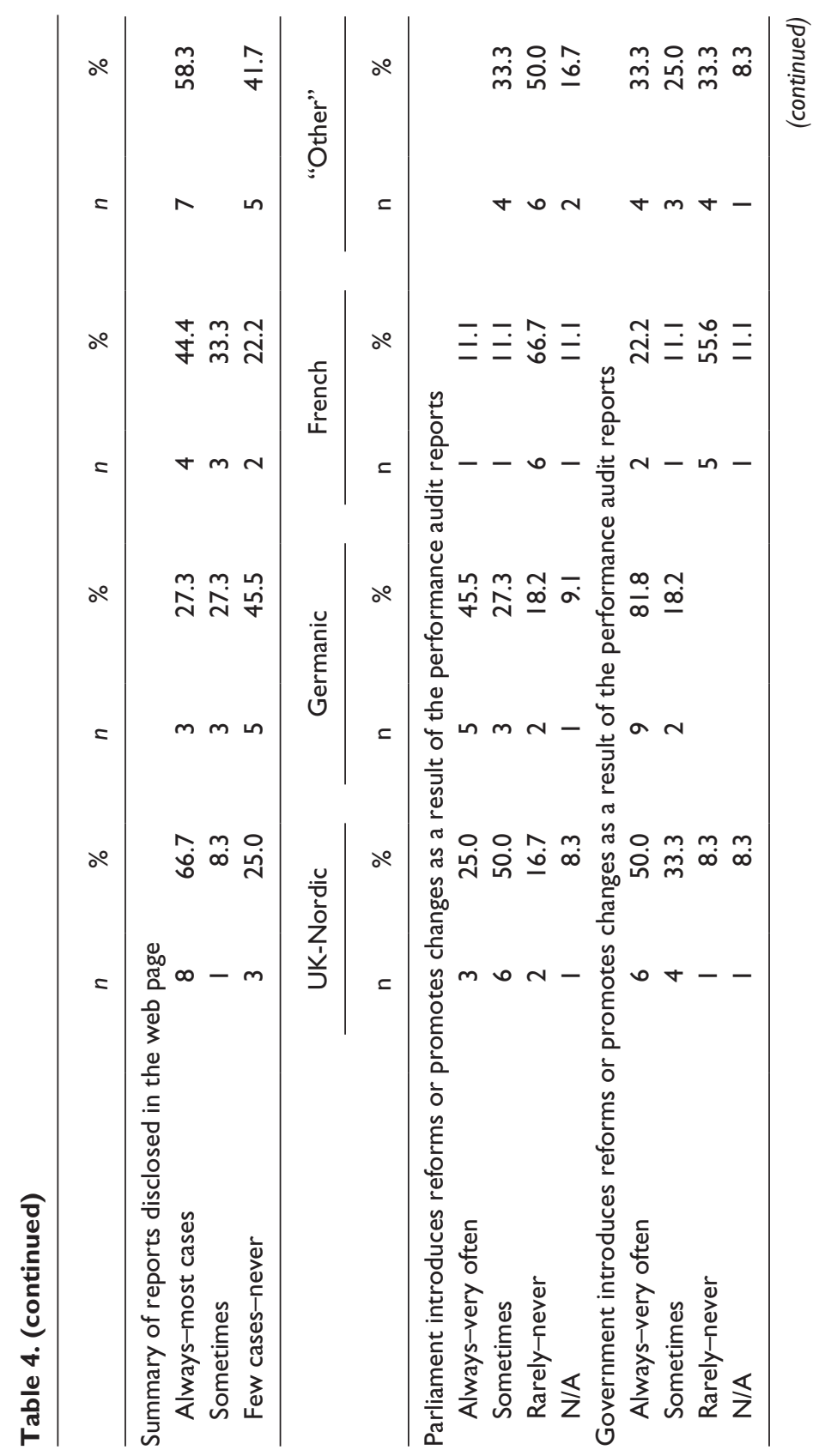




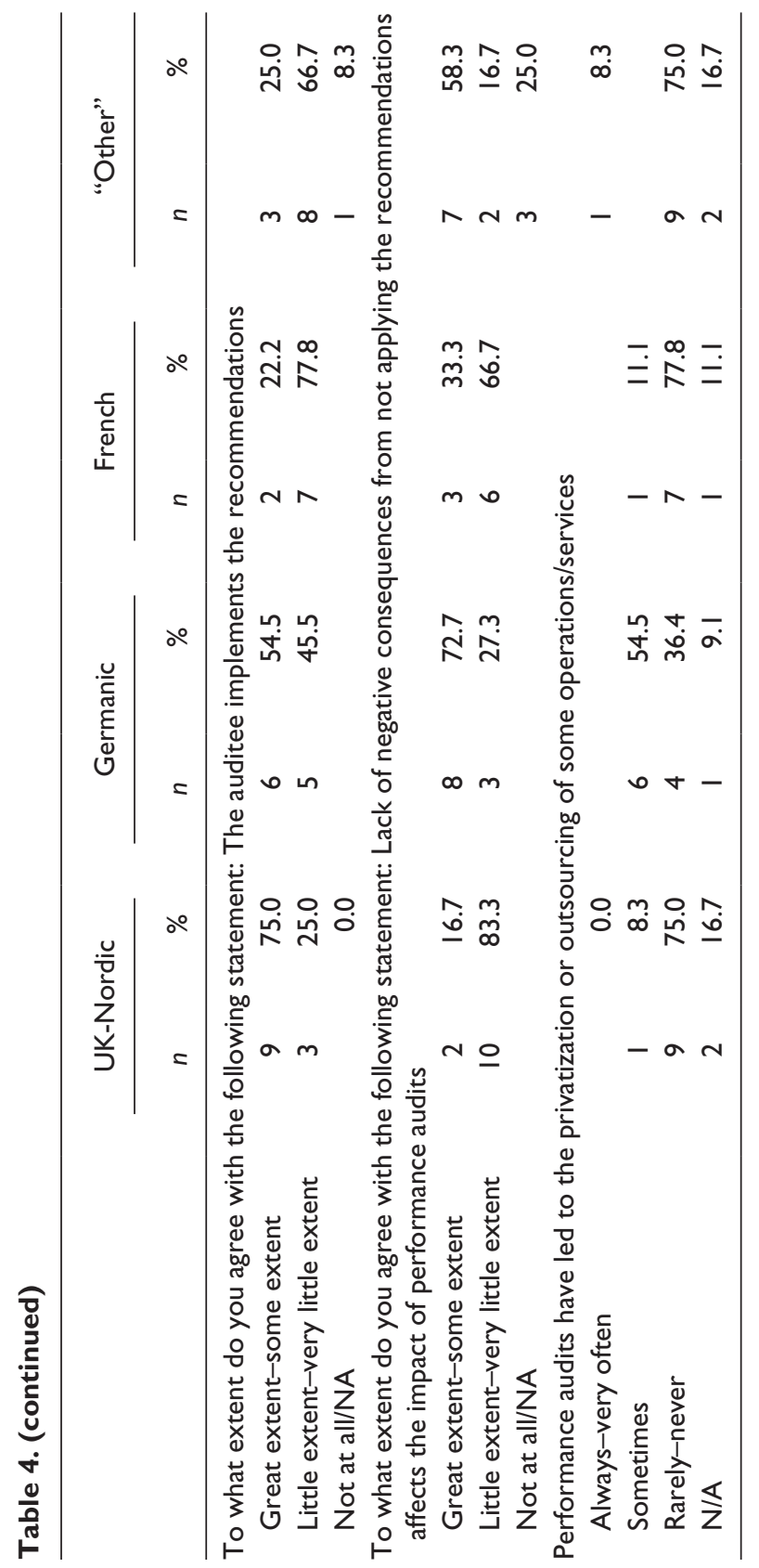


Almost all their performance reports are presented to parliament (90\%) where the RAI/SAI and the audited entity debate the content and conclusions of the audit report (Table 4). Only 36\% of the RAIs publish the full report in their websites (Table 4) and the rest only upload a summary. So, this group gives greater importance to reporting to parliaments than to the public.

Not surprisingly, it is in this group that the effect of the performance audits is greater in terms of reforms promoted by parliaments and governments and in outsourcing (Table 4). This group helps the audited entities to implement their recommendations. The participation of the audited entity in the parliamentary debate and the introduction of its opinion in the reports show the political will for the performance audits to have a real effect.

\section{Group 3-The French Group}

This group contains only French RAIs, all the French RAIs studied (Corse, Franche-Comte, Ile de France, Midi Pyrenees, Nord Pas Calais, Nouvelle Calédonie, Picardie, Poitou Charentes, and Polynésie) that carry out performance audits. Their homogeneous behavior is a consequence of the centralized French public auditing system, which makes them regional branches of the French SAI (the Court de Comptes and their RAIs share the same web with sub-pages for each RAI). The number of reports produced is lower than in the previous groups (see Table 2) even though they devote similar resources to performance auditing. They do not contract out or use external consultants. Most of the auditees do not have cost accounting, performance measures, and quantified objectives (Table 3).

The audit reports are rarely presented in parliament and governmental reforms have seldom been carried out after performance audits. The lack of parliamentary involvement should be balanced by the monitoring of the implementation of the auditing recommendations. In fact, these RAIs consider that the greatest limitation of their performance audits is the absence of any negative consequences from not implementing their recommendations.

In contrast with the Germanic group, this group shows a high level of transparency since the full reports are always uploaded onto the website. A summary is also published in $44 \%$ of the cases. The response of the entities audited is often provided on the web.

\section{Group 4-“Other"}

This group, with a low activity in performance auditing, is quite heterogeneous. It includes five SAIs-Cyprus, Czech Republic, Germany, Latvia, 
Lithuania, and Malta—and seven RAIs—Baden Württemberg and Brandenburg from Germany, and Andalusia, the Canary Islands, Catalonia, Navarra, and the Basque Country from Spain. The MDS representation (Figure 1) shows a great dispersion due to the variability of the responses.

Their performance audits have little effect because there is hardly any implementation of their recommendations or follow-up processes. The reports do not usually produce reforms. The few resources devoted to performance audits, the lack of specific personnel, and the low use of external experts may explain the few reports in this group. Furthermore, the entities audited do not usually have cost accounting, performance measures, and quantified objectives (see Table 3). This lack is an additional barrier to carrying out performance audits.

Performance audit indexes. The four groups previously identified present differences. To explore whether these differences are statistically significant, three indexes have been elaborated (see Table 5) and the MannWhitney test has been applied. The first index (A) combines the number of reports and effects of the performance audit activity. It will be used to analyze whether the effect of the UK-Nordic and the Germanic groups is noticeably different to the French and the "Other" groups. The B and C indexes have been elaborated considering the differences between the UKNordic and the Germanic groups, which are considered to be two different logics/public administration styles that have achieved a noticeable impact. The objective is to test whether significant differences exist between these two models. We have also applied the Mann-Whitney test to the French and the "Other" groups to see if they are closer to the UK-Nordic or the Germanic models.

Table 6 shows that the A index is higher in the UK-Nordic and the Germanic groups. The UK-Nordic model shows the highest effect in implementing recommendations by the entities audited and the Germanic group shows the highest effect in parliamentary and governmental reforms. The right side of the MDS exhibit represents the SAIs/RAIs whose performance audits have higher impacts (see Figure 1). The fact that the UK-Nordic model achieves effects through the implementation of recommendations by the entity audited while the Germanic model does so through parliamentary and governmental reforms suggests different valid approaches to implementing performance audit recommendations. It also explains why one group is in the top half of the MDS and the other in the bottom half. The scores achieved in the $\mathrm{B}$ and $\mathrm{C}$ indexes show that there are differences among the four groups identified in the way performance audits are introduced. 
Table 5. Performance Audit Indexes.

\begin{tabular}{|c|c|c|}
\hline $\begin{array}{l}\text { (A) Effect index } \\
\text { (maximum 20) }\end{array}$ & $\begin{array}{l}\text { (B) Anglo-American model } \\
\text { index (maximum 29) }\end{array}$ & $\begin{array}{l}\text { (C) Continental European } \\
\text { model index (maximum 29) }\end{array}$ \\
\hline $\begin{array}{l}\text { Number of reports per } \\
\text { year }(0-5)\end{array}$ & $\begin{array}{l}\text { Mainly in-house } \\
\text { performance audits, } \\
\text { contracting specialist (0-2) }\end{array}$ & $\begin{array}{l}\text { Performance audits are } \\
\text { mainly contracted out } \\
(0-2)\end{array}$ \\
\hline $\begin{array}{l}\text { Implementation of the } \\
\text { recommendations by } \\
\text { the auditee }(0-5)\end{array}$ & $\begin{array}{l}\text { Audited organizations have } \\
\text { cost accounting }(0-4), \\
\text { performance measures } \\
(0-4), \text { and objectives }(0-4)\end{array}$ & $\begin{array}{l}\text { Audited organizations have } \\
\text { cost accounting }(0-4)\end{array}$ \\
\hline $\begin{array}{l}\text { Introduction of reforms } \\
\text { by governments or } \\
\text { parliaments }(0-5)\end{array}$ & $\begin{array}{l}\text { Follow-up of the } \\
\text { recommendations }(0-5)\end{array}$ & $\begin{array}{l}\text { Help in the implementation } \\
\text { of recommendations }(0-5)\end{array}$ \\
\hline \multirow[t]{4}{*}{$\begin{array}{l}\text { Privatizations and } \\
\text { outsourcing resulting } \\
\text { from the audit reports } \\
(0-5)\end{array}$} & $\begin{array}{l}\text { Topics of social and } \\
\text { political significance in } \\
\text { addition to financial } \\
\text { significance }(0-3)\end{array}$ & $\begin{array}{l}\text { Topics of financial } \\
\text { significance }(0-I)\end{array}$ \\
\hline & $\begin{array}{l}\text { Full reports published on } \\
\text { the web }(0-5)\end{array}$ & $\begin{array}{l}\text { Summaries published } \\
\text { on the web (rarely full } \\
\text { reports) (summaries 0-5 } \\
\text { and full reports 0-5 with } \\
\text { reverse code) }\end{array}$ \\
\hline & $\begin{array}{l}\text { Low level of parliamentary } \\
\text { debate (RAI/SAI) (high } \\
\text { parliamentary debate } \\
\text { adds in the Continental } \\
\text { European model index) }\end{array}$ & $\begin{array}{l}\text { High level of parliamentary } \\
\text { debate (RAI/SAI, entity } \\
\text { audited, and councilor/ } \\
\text { minister) (debate } 0-5 \text { and } \\
\text { participants } 0-2 \text { ) }\end{array}$ \\
\hline & $\begin{array}{l}\text { Quality control mechanisms } \\
(0-2)\end{array}$ & \\
\hline
\end{tabular}

Note. RAI = Regional Audit Institutions; SAI = Supreme Audit Institutions.

As can be seen in Table 6, the differences in performance audit development between the UK-Nordic and the Germanic groups are statistically significant. Similarities between groups have appeared when two groups coincide in their low scores. For example, both the UK-Nordic and the French groups achieve a low score in the Continental European index and, for that reason, are similar. They are similar because neither of them is following the Continental European model. We can conclude that the two models, represented by indexes B and C, follow different strategies with regard to the implementation of the performance audit. The French and "Other" groups present a lower level of development and effects in performance audit. The French RAIs show a mixed model. They share public 


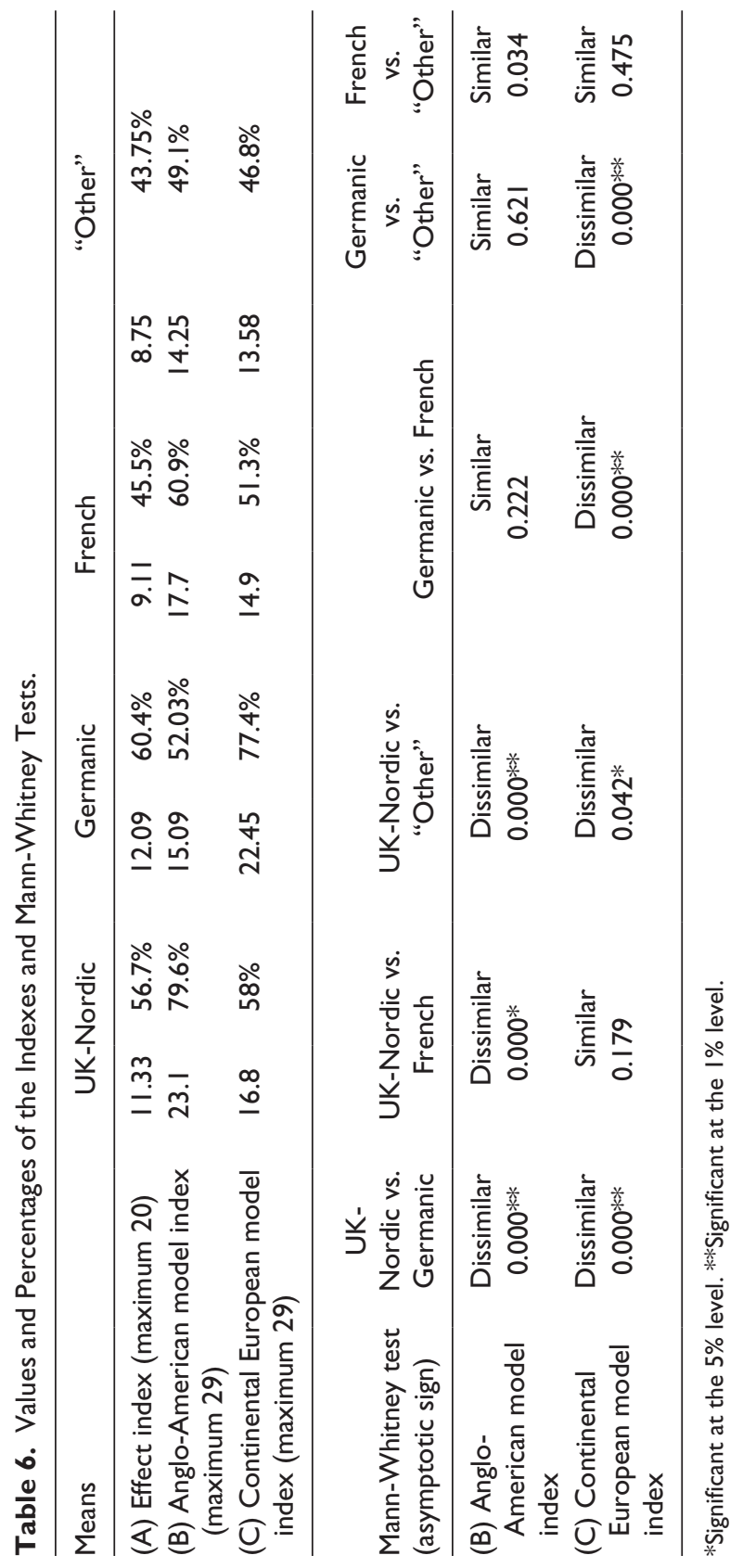


sector characteristics with the Germanic group, which explain their score in the Continental European model. However, they achieve a slightly higher mean in the Anglo-American model because, when changes resulting from performance audits are implemented, this is done by the auditees. This explains why the French RAIs are not statistically similar to the UK-Nordic and Germanic groups (see Table 6). The "Other" group achieves the lowest scores in all indexes, so it is not possible to a model of performance auditing.

\section{Discussion}

This study outlines the state of the art of performance audits and the effect they have in the European Union. Most audit institutions have extended their "watchdog" role toward assuming new competencies with the aim of detecting waste and inefficiency. Performance audits have been extensively implemented, at least at the "formal" level. However, not all SAIs/RAIs achieve an impact from their activity. Impact is measured considering the extent to which performance audit recommendations are implemented and how those recommendations are implemented.

Performance audits are supported by a legal mandate in all the countries studied, except in Poland. In fact, Polish RAIs do not carry out performance auditing. This suggests that a legal framework is a necessary condition for performance audit, especially in countries that have an administrative practice with a legalistic philosophy. As shown by Chelli, Durocher, and Richard (2014), regulation prompts organizations to comply with law to ensure organizational legitimacy. However, legislation has proven to be insufficient to generate an impact. Traditionally, the introduction of public sector initiatives, such as performance audits, has been explained by isomorphism. Isomorphism predicts that the adoption of performance audit may not always be driven by efficiency and effectiveness concerns but by the emulation of best practices implemented by other significant organizations (DiMaggio \& Powell, 1983). So, not all public sector initiatives produce an impact. As we show, the French and the "Other" groups produce no effect, as has happened in these countries with other public sector reforms (Pina et al., 2009; Rouban, 2008; Torres et al., 2011). As van Zyl et al. (2009) argued, some audit institutions consider that one political challenge is the lack of authority to ensure that their recommendations are implemented. The results confirm that there are different ways for performance audits to produce impact. In the UK-Nordic group impact was achieved through the implementation of the recommendations by the 
entity audited and, in the Germanic group, it was obtained through reforms carried out by parliament.

Lounsbury (2001, 2007, 2008), Covaleski, Dirsmith, and Weiss (2013), and Scott (2008) presented a refinement of institutional theory focused on the primacy of culture and on the existence of multiple and competing logics (Friedland \& Alford, 1991; Lounsbury, 2007). This refinement helps to understand various configurations of performance audit that have an impact. These different configurations are highly conditioned by logics/public administrative styles, in our article the Anglo-American and the Continental European models. It is confirmed that the adoption of the performance audit depends on previous traditions.

In the Anglo-American model, the impact of performance audits is mainly due to the implementation of recommendations by the entities audited. The change process initiated by the recommendations finishes with the followup audits. The UK-Nordic group, which follows this model, also includes countries that are traditionally considered Continental European, such as Portugal, Lithuania, and Hungary. These countries seem to have followed the trend of the NPM with greater interest. This confirms that the search for internationally recognized practices still helps to explain how reforms are diffused. At the same time, the concept of logic/public administration style helps to explain why the cases of Hungary and Portugal show characteristics, such as delayed reports, that illustrate that moving away from their traditional administrative culture is not easy. In many cases, their financial audits are fully carried out by private firms and performance audits are done in-house and use external consultants for specific issues. The lack of distinction between private and public sector auditing has led to the dismantling of the Audit Commission of England, an independent public sector entity in charge of local governments' and NHS authorities' auditing that existed between April 1, 1983 and March 31, 2015, and the transference of its activity to the private sector.

In the Continental European model, followed by German and Austrian RAIs, the effect of performance audits comes primarily from the reforms promoted by parliament. This way of introducing reforms explains why, in this group, there are lower levels of follow-up audits. These RAIs show elements of bureaucratic cultures in which the crucial budgetary audit is complemented with economy audits. The legal training of civil servants in Germanic countries may explain why they frequently contract out performance audits. The debates in parliament between the entity audited, the auditor, and the politician responsible for the audited entity about the results of the audits and the reforms undertaken show that this public law model 
produces effects. The negative image that bureaucratic cultures have had during recent decades, and the lack of international dissemination of their practices, have led to a limited diffusion of the Germanic model.

The French and the "Other" are the groups with the lowest effect. In the French group, the lack of parliamentary action suggests that recommendations should be directly implemented by the entities audited. In the "Other" group, performance auditing seems testimonial. In this group, the audit institutions, based on their public sector characteristics and traditions, may choose either the Anglo-American or the Germanic model. In fact, the position in the MDS map of the German and the Czech SAIs seems to anticipate that, once they improve the involvement of their parliament in the implementation of performance audit results, they will move toward the Germanic model.

Finally, the level of decentralization creates differences within the same country. In France, where decentralization is lower, there is greater homogeneity while, in Germany, the higher decentralization leads to greater heterogeneity.

\section{Conclusion}

The necessary, but not sufficient, condition for performance audits to generate impact is the legal framework. The absence of legal requirements shows a lack of political will that leads to shortages of resources with which to carry out performance audits. The sufficient condition is the implementation of the recommendations. Otherwise, performance audits become a source of waste and the resources used could be better used for other purposes.

Some financial reforms, especially those related to the budget, accounting, and performance measures, condition the role of performance audits and their consequences. In the UK-Nordic group, the audited entities have cost indicators, performance measures and defined objectives. All this information allows the RAIs/SAIs to carry out economy, efficiency, and effectiveness audits more easily. In the Germanic group, it is more frequent to find cost indicators than performance measures, which explains why the activity in performance audits of the RAIs/SAIs is focused on economy topics.

There is no single way to obtain impacts from performance audits. Institutional theory and the concept of logics/public administration styles help us to understand variations in the practice of performance audits. The Anglo-American model is not the only approach in the EU to carrying out performance audits and implementing recommendations, although it is still the model of reference in many cases. Actions are taken, in the 
Anglo-American environment, through the direct implementation of the audit recommendations by the audited entities-which requires follow-up processes - and, in the case of Germanic countries, through parliamentary action. Performance auditing usually involves the collaboration of the private sector because both the UK-Nordic and the Germanic groups use external support. The legal training of civil servants in Continental Europe seems to affect the level of contracting out.

Future studies could analyze the savings achieved by these recommendations to conclude whether performance audits are cost-effective. This study considers only one source of variation (Power, 2003) in performance audit practice, that is, the influence of logics/public administration styles. Future studies should analyze others, in particular, in countries where territorial decentralization creates heterogeneity within the country and/or different levels of activity between the SAI and the RAIs. The configuration of audit institutions as Offices or Courts is a variable that may condition performance audit developments, in this study this effect is embedded in the concept of public administration style rather than studied in isolation. Future studies could analyze this effect in isolation as done previously by Noussi (2012).

\section{Appendix A}

\section{Participating RAls and SAls}

Regional Audit Institutions. AUSTRIA

Kärntner Landesrechnungshof-www.landesrechnungshof.ktn.gv.at Landesrechnungshof Tirol—www.tirol.gv.at/landtag/landesrechnungshof Landes-Rechnungshof Vorarlberg—http://www.lrh-v.at/

Niederösterreichischer Landesrechnungshof-www.lrh-noe.at

Oberösterreichischer Landesrechnungshof-www.lrh-ooe.at

Salzburger Landesrechnungshof—-www.salzburg.gv.at/lt-rechnungshof. htm

\section{FRANCE}

Chambre régionale des comptes de Corse —www.ccomptes.fr/..../Corse Chambre régionale des comptes de Franche-Comté—http://www.ccomptes. $\mathrm{fr} / . .$. /Bourgogne-Franche-Comte

Chambre régionale des comptes d'Ile-de-France-www.ccomptes.fr/.../ Ile-de-France

Chambre régionale des comptes de Midi-Pyrénées-www.ccomptes. $\mathrm{fr} / . . . /$ Midi-Pyrenees 
Chambre régionale des comptes du Nord-Pas-de-Calais-www.ccomptes. $\mathrm{fr} / . . . /$ Nord-Pas-de-Calais

Chambre régionale des comptes de Picardie — www.ccomptes.fr/.../Picardie Chambre régionale des comptes de Poitou-Charentes-www.ccomptes. $\mathrm{fr} / . . . /$ Aquitaine-Poitou-Charentes

Chambre territoriale des comptes de Nouvelle-Calédonie-http://www. ccomptes.fr//Nouvelle-Caledonie

Chambre territoriale des comptes de Polynésie française-http://www. ccomptes.fr//Polynesie-francaise

Chambre régionale des comptes du Limousin (we do not carry out performance audit in the strict sense)—www.ccomptes.fr//Centre-Limousin

\section{GERMANY}

Bayerischer Oberster Rechnungshof-www.orh.bayern.de LandesrechnungshofBrandenburg — www.brandenburg.de/landesrechnungshof

Landesrechnungshof Mecklenburg-Vorpommern-www.lrh-mv.de Landesrechnungshof Sachsen-Anhalt-www.lrh.sachsen-anhalt.de Niedersächsischer Landesrechnungshof — www.lrh.niedersachsen.de Rechnungshof Baden-Württemberg-www.rechnungshof.baden-wuerttemberg.de

Rechnungshof der Freien und Hansestadt Hamburg-www.hamburg.de/ rechnungshof

Rechnungshof Rheinland-Pfalz-www.rechnungshof-rlp.de

Sächsischer Rechnungshof (we cannot answer, we do not differentiate) www.srh.sachsen.de

\section{POLAND}

Regional Chamber of Audit in Bydgoszcz (No performance audit)—www. bydgoszcz.rio.gov.pl

Regional Chamber of Audit in Szczecin (No performance audit)—www. szczecin.rio.gov.pl

Regionalna Izba Obrachunkowa w Gdańsku (No performance audit)www.bip.gdansk.rio.gov.pl

Regionalna Izba Obrachunkowa w Krakowie (No performance audit)_ www.krakow.rio.gov.pl

Regionalna Izby Obrachunkowa w Rzeszowie (No performance audit)— www.rzeszow.rio.gov.pl

Regionalna Izby Obrachunkowa-w-Zielonej Górze (No performance audit)—www.zielonagora.rio.gov.pl 


\section{SPAIN}

Audiencia de Cuentas de Canarias-www.acuentascanarias.org

Cámara de Comptos de Navarra-www.camaradecomptos.org

Cámara de Cuentas de Andalucía-www.ccuentas.es

Sindicatura de Cuentas de Cataluña-www.sindicatura.cat

Sindicatura de Cuentas de las Islas Baleares (NO)—www.sindicaturaib. org

Sindicatura de Cuentas de Castilla-La Mancha (NO)_-www.sindicaturaclm.es/paginas/index.php

Sindicatura de Cuentas del Principado de Asturias (NO)—www.sindicastur.es

Tribunal Vasco de Cuentas Públicas-www.tvcp.org

\section{THE UNITED KINGDOM}

Audit Commission of England—www.audit-commission.gov.uk

Audit Scotland-www.audit-scotland.gov.uk

Wales Audit Office-www.wao.gov.uk

\section{Supreme Audit Institutions}

Auditor General and the Audit Office of the Republic of Cyprus-www. audit.gov.cy

Bundesrechnungshof (Germany)—www.bundesrechnungshof.de

Cour des comptes (Belgium)—www.ccrek.be

Latvijas Republikas Valsts Kontrole (Latvia)—www.lrvk.gov.lv

National Audit Office (Malta)—www.nao.gov.mt

Nejvyssi kontrolni Urad (Czech Republic)—www.nku.cz

Rigsrevisionen (Denmark)—www.rigsrevisionen.dk

Riksrevisionen (Sweden)—www.riksrevisionen.se

Riksrevisjonen (Norway)—www.riksrevisjonen.no

State Audit Office of Hungary-www.asz.hu

Tribunal de Contas (Portugal)—www.tcontas.pt

Valstybes Kontroliere (Lithuania)—www.vkontrole.lt

\section{European Union}

European Court of Auditors-www.eca.europa.eu 


\section{Appendix B}

\section{Cluster Analysis (Dendogram-Ward Method)}

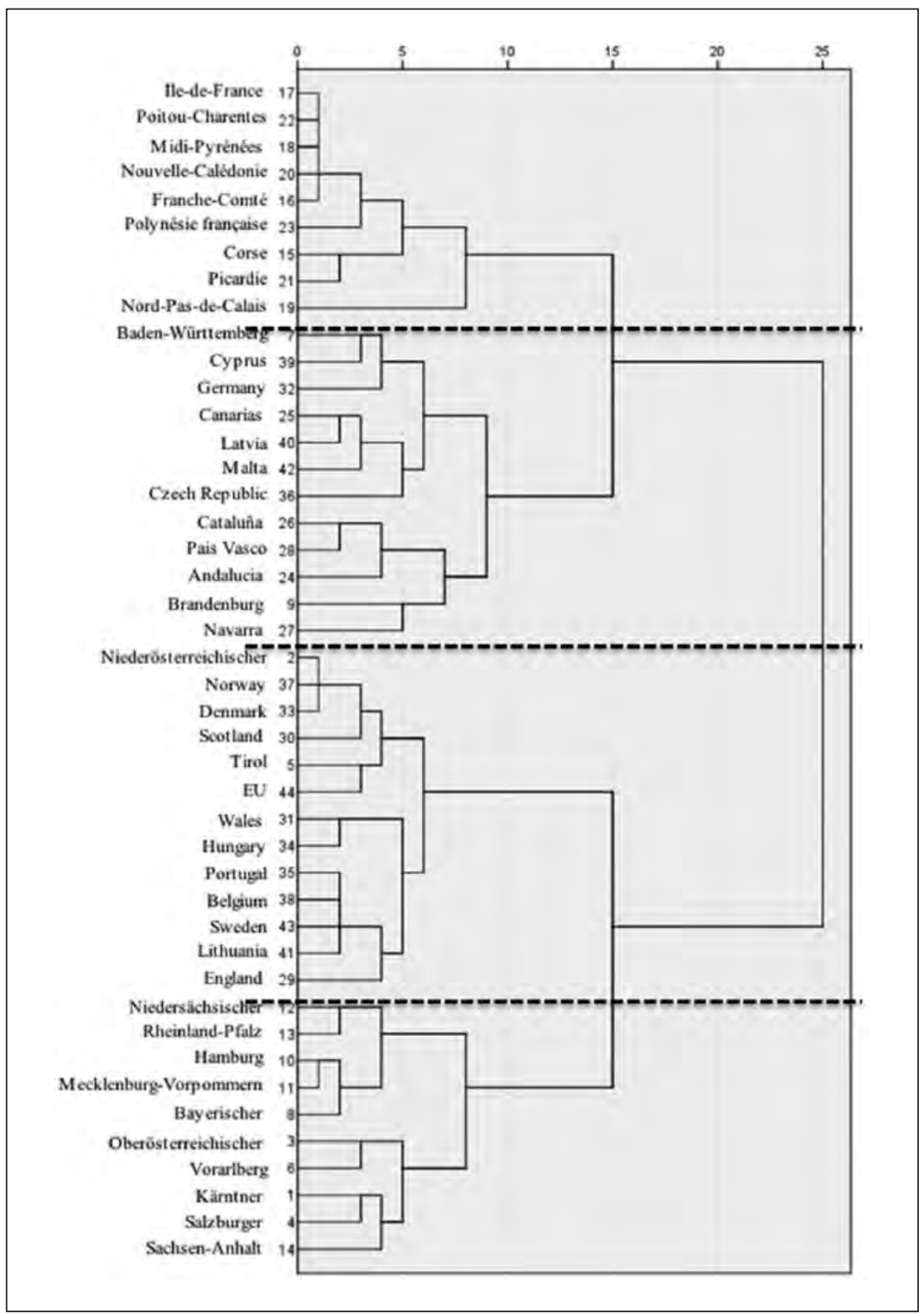




\section{Acknowledgments}

The authors want to thank the European Organization of Regional External Public Finance Audit Institutions (EURORAI) for their support in carrying out this study.

\section{Declaration of Conflicting Interests}

The author(s) declared no potential conflicts of interest with respect to the research, authorship, and/or publication of this article.

\section{Funding}

The author(s) disclosed receipt of the following financial support for the research, authorship, and/or publication of this article: This study has been carried out with the financial support of the Spanish National R\&D Plan through research project ECO2015-66240P (MINECO/FEDER) and of the Regional Government of Aragón and the European Social Fund through Research Project S05.

\section{Notes}

1. International Seminar "Auditing - a consideration of the impact of the wider economic downturn on the role, coverage and resourcing of public audit” of EURORAI held in Edinburgh 2014. Members of Audit Scotland, Niederösterreichischer and Rekenkamer Rotterdam, among others, highlighted the importance of performance audit in the context of the economic downturn.

2. With regard to the results of the performance audits, the public sector literature uses the words outcomes, impacts, actual results, effects, and/or consequences. We will use the word impact. Impact is defined as "the effect that something has on somebody/something.” Our focus is to what extent performance audit recommendations have led to changes.

3. The accountability dimension of the performance audit report is not denied, but it is outside the scope of this study. Important work in this area has been carried out by Reichborn-Kjennerud (2013, 2015).

4. The concept of logic refers to broad cultural beliefs and rules that structure cognition and fundamentally shape decision-making and action (Lounsbury, 2007, 2008). Collective beliefs are objectified and thus "constitute social reality" (Greenwood, Hinings, \& Suddaby, 2002) and create institutional logics.

5. Although Norway is not an EU 27 country, the questionnaire was sent to obtain a wider picture of the Nordic countries.

6. Countries such as Portugal and the Netherlands, where audits offices are only for two specific regions (Portugal) and for specific cities (the Netherlands), and which, therefore, do not have a country-wide structure for regional auditing, were excluded from the study.

7. All the countries with RAIs are represented in the sample (Austria, France, Germany, Poland, Spain, and the United Kingdom). 
8. A descriptive analysis of the study was sent for validation to respondents.

9. A full content analysis is outside the scope of this work. Web translation tools were used to overcome the language barriers.

10. Data obtained from the analysis of the reports published on the website.

\section{References}

Alon, G. (2007). State audit and the media as the watchdogs of democracy-A comparative view. Iyunim-The Periodical of the Office of the State Comptroller and Ombudsman, 61, 55-100.

Arthur, A., Rydland, L. T., \& Amundsen, K. (2012). The user perspective in performance auditing-A case study of Norway. American Journal of Evaluation, 33, 44-59.

Blume, L., \& Voigt, S. (2007). Supreme audit institutions: Supremely superfluous? A cross country assessment. Centre for Economic Research (ICER). Working Paper No. 3/2007

Bouckaert, G., \& Peters, B. G. (2002). Performance measurement and management: The Achilles' heel in administrative modernization. Public Performance \& Management Review, 25, 359-362.

Brown, R. E., \& Craft, R. (1980). Auditing and public administration: The unrealized partnership. Public Administration Review, 40, 259-265.

Burns, J., \& Scapens, R. W. (2000). Conceptualizing management accounting change: An institutional framework. Management Accounting Research, 11, 3-25.

Campbell, J. (2004). Institutional change and globalization. Princeton, NJ: Princeton University Press.

Chelli, M., Durocher, S., \& Richard, J. (2014). France’s new economic regulations: Insights from institutional legitimacy theory. Accounting, Auditing \& Accountability Journal, 27, 283-316.

Covaleski, M. A., Dirsmith, M. W., \& Weiss, J. M. (2013). The social construction, challenge and transformation of a budgetary regime: The endogenization of welfare regulation by institutional entrepreneurs. Accounting, Organizations and Society, 38, 333-364.

DiMaggio, P. J., \& Powell, W. (1983). The Iron Cage Revisited-Institutional isomorphism and collective rationality in organizational fields. American Sociological Review, 48, 147-160.

Dunleavy, P., \& Hood, C. (1994). From old public-administration to new public management. Public Money \& Management, 14, 9-16.

Friedland, R., \& Alford, R. R. (1991). Bringing society back in: Symbols, practices and institutional contradictions. In W. W. Powell \& P. DiMaggio (Eds.), The new institutionalism in organizational analysis (pp. 232-266). Chicago, IL: The University of Chicago Press.

Greenwood, R., Hinings, C. R., \& Suddaby, R. (2002). Theorizing change: The role of professional associations in the transformation of institutionalized fields [Article]. Academy of Management Journal, 45, 58-80. 
Hatherly, D. J., \& Parker, L. D. (1988). Performance auditing outcomes: A comparative study. Financial Accountability \& Management, 4, 21-41.

Hood, C. (1995). The new public management in the 1980s-Variations on a theme. Accounting Organizations and Society, 20, 93-109.

Jann, W. (2003). State, administration and governance in Germany: Competing traditions and dominant narratives [Article]. Public Administration, 81, 95-118.

Johnsen, Å. (2005). What does 25 years of experience tell us about the state of performance measurement in public policy and management? Public Money \& Management, 25, 9-17.

Johnston, W. P. (1988). Increasing evaluation use: Some observations based on the results of the U.S. G.A.O. New Directions for Program Evaluation, 39, 75-84.

Kickert, W. (Ed.). (1997). Public management in the United States and Europe. Cheltenham, UK: Edward Elgar.

Kickert, W. (2005). Distinctiveness in the study of public management in Europe. Public Management Review, 7, 537-563.

Lonsdale, J. (2000). Developments in value-for-money audit methods: Impacts and implications. International Review of Administrative Sciences, 66, 73-89.

Lounsbury, M. (2001). Institutional sources of practice variation: Staffing college and university recycling programs. Administrative Science Quarterly, 46, 29-56.

Lounsbury, M. (2007). A tale of two cities: Competing logics and practice variation in the professionalizing of mutual funds. Academy of Management Journal, 50, 289-307.

Lounsbury, M. (2008). Institutional rationality and practice variation: New directions in the institutional analysis of practice. Accounting, Organizations and Society, 33, 349-361.

Lounsbury, M., \& Ventresca, M. (2002). Social structure and organizations revisited. Research in the Sociology of Organizations, 19, 1-36.

Meyer, J. W., \& Rowan, B. (1977). Institutionalized organizations: Formal structure as myth and ceremony. The American Journal of Sociology, 83, 340-363.

Milgrom, T., \& Schwartz, R. (2008). Israel's auditor as policy change agent: The case of water policy. International Journal of Public Administration, 31, 862-877.

Morin, D. (2001). Influence of value for money audit on public administrations: Looking beyond appearances. Financial Accountability \& Management, 17, 99-117.

Morin, D. (2004). Measuring the impact of value-for-money audits: A model for surveying audited managers. Canadian Public Administration, 47, 141-164.

Morin, D. (2008). Auditors general's universe revisited. Managerial Auditing Journal, 23, 697-720.

Noussi, K. (2012). How public accountability is institutionalized. Austria: University of Vienna.

Oliver, C. (1991). Strategic responses to institutional processes. Academy of Management Review, 16, 145-179.

Ongaro, E. (2008). Introduction: The reform of public management in France, Greece, Italy, Portugal and Spain. The International Journal of Public Sector Management, 21, 101-117. 
Pina, V., Torres, L., \& Yetano, A. (2009). Accrual accounting in EU local governments: One method, several approaches. European Accounting Review, 18, 765-807.

Pollitt, C. (2003). Performance audit in Western Europe: Trends and choices. Critical Perspectives on Accounting, 14, 157-170.

Pollitt, C. (2010). Cuts and reforms: Public services as we move into a new era. Society and Economy, 32, 17-31.

Pollitt, C., \& Bouckaert, G. (2011). Public management reform: A comparative analysis: New public management, governance and the neo-Weberian State. Oxford, UK: Oxford University Press.

Pollitt, C., Gire, X., Lonsdale, J., Mull, R., Summa, H., \& Waerness, M. (1999). Performance or compliance? Performance audit and public management in five countries. Oxford, UK: Oxford University Press.

Power, M. (2003). Evaluating the Audit Explosion. Law \& Policy, 25, 185-202,

Reichborn-Kjennerud, K. (2013). Political accountability and performance audit: The case of The Auditor General in Norway. Public Administration, 91, 680-695.

Reichborn-Kjennerud, K. (2014). Performance audit and the importance of the public debate. Evaluation, 20, 368-385.

Reichborn-Kjennerud, K. (2015). Resistance to control-Norwegian Ministries' and Agencies' reactions to performance audit. Public Organization Review, 15, 17-32.

Ribeiro, J. A., \& Scapens, R. W. (2006). Institutional theories in management accounting change: Contributions, issues and paths for development. Qualitative Research in Accounting \& Management, 3, 94-111.

Rouban, L. (2008). Reform without doctrine: Public management in France. The International Journal of Public Sector Management, 21, 133-149.

Schelker, M. (2008). Auditors and corporate governance: Evidence from the public sector. Retrieved from http://ssrn.com/abstract=959392

Scott, W. R. (2008). Approaching adulthood: The maturing of institutional theory. Theory and Society, 37, 427-442.

Shand, D., \& Arnberg, M. (1996). Background paper. In responsive government: Service quality initiatives. Paris, France: Organisation for Economic Cooperation and Development.

Siti-Nabiha, A. K., \& Scapens, R. W. (2005). Stability and change: An institutionalist study of management accounting change. Accounting, Auditing \& Accountability Journal, 18, 44-73.

Streib, G. D., \& Poister, T. H. (1999). Assessing the validity, legitimacy and functionality of performance measurement systems in municipal governments. American Review of Public Administration, 29, 107-123.

Tillema, S., \& ter Bogt, H. J. (2010). Performance auditing: Improving the quality of political and democratic processes? Critical Perspectives on Accounting, 21, 754-769.

Torres, L., \& Pina, V. (1999). An empirical study on the performance of supreme audit. Institution in European Union privatization. European Accounting Review, 8, 777-795. 
Torres, L., Pina, V., \& Yetano, A. (2011). Performance measurement in Spanish local governments. A cross-case comparison study. Public Administration, 89, 1081-1109.

Van Loocke, E., \& Put, V. (2011). The impact of performance audits: A review of the existing evidence. In J. Lonsdale, P. Wilkins, \& T. Ling (Eds.), Performance auditing: Contributing to accountability in democratic government (pp. 175208). Cheltenham, UK: Edward Elgar.

van Zyl, A., Ramkumar, V., \& de Rencio, P. (2009). Responding to the challenges of Supreme Audit Institutions: Can legislatures and civil society help? U4Issue, 1. Retrieved from http://www.u4.no/

Yetano, A. (2005). Value for money audits and e-government: Benchmarking best practices. Public Performance \& Management Review, 29, 111-124.

Yetano, A. (2014). The diffusion of value for money auditing at regional level: A comparative study of the United Kingdom, Germany and Spain [Article]. Gestion Y Politica Publica, 23, 421-464.

\section{Author Biographies}

Lourdes Torres is full professor of Public Sector Accounting at the University of Zaragoza (Spain). Her research is focused on accounting, management, and auditing of public sector reforms and she has published articles many well-known international journals.

Ana Yetano is currently associate professor at the University of Zaragoza (Spain). Her research fields are performance measurement and management at local government level and performance audits in the public sector. She has also explored citizen participation processes.

Vicente Pina is full professor of Accounting and Finance at the University of Zaragoza (Spain). His research is focused on the accounting, management, and auditing of public sector reforms and has published articles in leading journal of Public Administration. 